\title{
УДК: 159.955.5
}

Ткачук Ольга Володимирівна, аспірант кафедри психології та педагогіки Національного університету «Острозька академія». e-mail: delivery4olya@gmail.com

\section{ВПЛИВ ТОЧНОСТІ МЕТАКОГНІТИВНОГО МОНІТОРИНГУ НА УСПІШНІСТЬ НАВЧАЛЬНОЇ ДІЯЛЬНОСТІ}

\begin{abstract}
Анотація
У статті здійснено теоретичний аналіз досліджень щодо впливу
\end{abstract} точності метакогнітивного моніторингу на успішність навчальної діяльності. Під метакогнітивним моніторингом ми розуміємо здатність до оцінки поточного стану когнітивної активності та спрямованість на відслідковування того, чи суб'єкт правильно вирішує поставлену проблему, а також на встановлення рівня розуміння опрацьованого матеріалу.

Розглядаючи властивості метакогнітивного моніторингу, слід звернути увагу на його точність. Точність метакогнітивного моніторингу дозволяє індивіду успішно користуватись ефективними метакогнітивними стратегіями для досягнення цілей пізнання. Це дає перевагу у плануванні процесів обробки інформації і визначенні ефективних стратегій в майбутньому.

Судження метакогнітивного моніторингу $є$ важливим джерелом регуляції студентом процесу пізнавальної діяльності під час засвоєння інформації. Очевидно, що у випадку надмірної впевненості, при запам'ятовуванні навчального матеріалу, студент приділятиме мало уваги для його вивчення, оскільки помилково вважатиме, що засвоїв його. Натомість, при недооцінці власних здібностей, студент витрачатиме надмірно багато зусиль та часу для опрацювання інформації.

Основні тенденції зв'язку точності метакогнітивного моніторингу та успішності навчальної діяльності представлені такими твердженнями: високі 
показники розвитку моніторингу, виміряні за допомогою різних варіантів опитувальників, позитивно корелюють 3 навчальними досягненнями $\mathrm{i}$ успішністю виконання тестів знань; учні та студенти, які демонструють більш точний метакогнітивний моніторинг успішності виконання тестів знань, мають більш високі бали по цим тестам, а також мають більш високі показники навчальної успішності; учні та студенти, які демонструють низькі показники виконання тестів знання, а також невисоку академічну успішність, схильні переоцінювати свої знання.

Ключові слова: метакогнітивні процеси, метакогнітивний моніторинг, навчальна діяльність, надмірна впевненість, надмірна невпевненість, калібрація.

Ткачук Ольга Владимировна, аспирант кафедры психологии и педагогики Национального университета «Острожская академия».

\title{
ВЛИЯНИЕ ТОЧНОСТИ МЕТАКОГНИТИВНОГО МОНИТОРИНГА НА УСПЕШНОСТЬ УЧЕБНОЙ ДЕЯТЕЛЬНОСТИ
}

\begin{abstract}
Аннотация
В статье осуществлен теоретический анализ исследований влияния точности метакогнитивного мониторинга на успешность учебной деятельности. Под метакогнитивным мониторингом мы понимаем способность к оценке текущего состояния когнитивной активности и направленость на отслеживание того, правильно ли субъект решает поставленную проблему, а также на установление уровня понимания обработанного материала.

Рассматривая свойства метакогнитивного мониторинга, следует обратить внимание на его точность. Точность метакогнитивного мониторинга позволяет индивиду успешно пользоваться эффективными метакогнитивными стратегиями для достижения целей познания. Это дает
\end{abstract}


преимущество в планировании процессов обработки информации и определении эффективных стратегий в будущем.

Суждение метакогнитивного мониторинга является важным источником регуляции студентом процессов познавательной деятельности во время усвоения информации. Очевидно, что в случае чрезмерной уверенности, при запоминании учебного материала, студент уделяет мало внимания для его изучения, поскольку ошибочно считает, что усвоил его. Зато, при недооценке собственных способностей, студент будет тратить чрезмерно много усилий и времени для обработки информации.

Основные тенденции связи точности метакогнитивного мониторинга и успешности учебной деятельности представлены следующими утверждениями: высокие показатели развития мониторинга, измеренные с помощью различных вариантов опросников, положительно коррелируют с учебными достижениями и успешностью выполнения тестов знаний; учащиеся и студенты, которые демонстрируют более точный метакогнитивный мониторинг успешности выполнения тестов знаний, имеют более высокие баллы по этим тестам, а также имеют более высокие показатели учебной успеваемости; учащиеся и студенты, которые демонстрируют низкие показатели выполнения тестов знания, а также невысокую академическую успеваемость, склонны переоценивать свои знания.

Ключевые слова: метакогнитивные процессы, метакогнитивный мониторинг, учебная деятельность, сверхуверенность, сверхнеуверенность, калибрация. 
Olha Tkachuk, postgraduate student of department of psychology and pedagogy, National University of Ostroh Academy

\title{
INFLUENCE OF THE ACCURACY OF METACOGNITIVE MONITORING ON THE SUCCESS OF LEARNING ACTIVITY
}

\begin{abstract}
Summary
The theoretical analysis of the researches on the influence of accuracy of metacognitive monitoring on the success of educational activity was carried out in the article. By metacognitive monitoring, we mean the ability to assess the current state of cognitive activity and the focus on tracking whether the subject is correct on the problem posed, and on establishing a level of understanding of the processed material.

When considering the properties of metacognitive monitoring, one should pay attention to its accuracy. The precision of metacognitive monitoring allows an individual to successfully use effective metacognitive strategies to achieve the goals of cognition. This provides an advantage in planning information processing processes and identifying effective strategies in the future.

The judgments of metacognitive monitoring are an important source of student control of cognitive processes during the acquisition of information. Obviously, in the case of excessive assurance, when memorizing the educational material, the student does not pay enough attention to study it, as he mistakenly believes that he has learnt it. However, underestimating its own abilities, the student will spend too much effort and time to process the information.

The main trends in the accuracy of metacognitive monitoring and the success of learning activities are presented by the following assertions: high indicators of monitoring development, measured by various questionnaires, correlate positively with academic achievements and the success of the implementation of knowledge tests; School students and college students who demonstrate more precise metacognitive monitoring of the success of the tests of
\end{abstract}


knowledge, have higher scores on these tests, and also have higher rates of academic performance; School students and college students who demonstrate low performance of knowledge tests, as well as low academic performance, tend to reevaluate their knowledge.

Key words: metacognitive processes, metacognitive monitoring, learning activity, overconfidence, underconfidence, calibration.

Постановка проблеми. Вивчення метакогнітивного моніторингу є важливим напрямом у галузі когнітивної психології. Точність метакогнітивного моніторингу $є$ не тільки фактором успішності та ефективності навчальної діяльності, але й відіграє ключову роль в усіх сферах діяльності особистості, оскільки дозволяє ефективно здійснювати пізнавальну діяльність. Метакогнітивний моніторинг - це здатність до оцінки поточного стану когнітивної активності та спрямований на відслідковування того, чи суб’єкт правильно вирішує поставлену проблему, а також на встановлення рівня розуміння опрацьованого матеріалу.

Очевидною $\epsilon$ ключова роль метакогнітивного моніторингу в навчальному процесі. Планування рішення навчальної задачі, відслідковування розуміння вивченого матеріалу та оцінка ефективності виконання навчальних задач - усе це є складовими процесів метапізнання, а саме проявом рівня розвитку точності метакогнітивного моніторингу. Високий рівень розвитку цього процесу є необхідною умовою академічної успішності студентів.

Аналіз останніх досліджень та публікацій. В вітчизняній та зарубіжній літературі метакогнітивні процеси розглядаються як фактор успішності пізнавальної діяльності і визначають іiі продуктивність (А. Карпов, М. Холодна, Б. Величковський, Ю. Скворцова, Е. Корнілов, Е. Савін, А. Фомін). Т. Доцевич, розглядаючи напрями досліджень метакогнітивних процесів, виводить окрему категорію: практичне застосування діагностики 
метапізнання у галузі освіти. О. Лазарєва характеризує метакогнітивний моніторинг процесу розуміння наукового тексту. Е. Савіним та А. Фоміним приділяється увага ролі узагальнених та предметно-специфічних метакогнітивних навичок у процесі навчальної діяльності. Ряд зарубіжних вчених, зокрема Дж. Барнет, Л. Болл, П. Вайн, А. Вінман, Л. Гарвалія, П. Грімс, П. Джаслін, Д. Джеймсон-Ноел, А. Коріат, М. Кредлер, Л. Нарренс,Т. Нельсон, Дж. Нетфілд, Л. Флейнелі, Д. Хакер, Дж. Хайксон експериментально вивчають особливості прояву метакогнітивного моніторингу в процесі навчальної діяльності.

Постановка завдання. На основі викладеного можна сформулювати завдання дослідження, яке полягає у теоретичному аналізі зв’язку між точністю метакогнітивного моніторингу та успішністю навчальної діяльності.

Виклад основного матеріалу дослідження. На сьогодні дослідження метакогнітивних процесів в навчальній діяльності включають теоретичний та емпіричний аналіз різних явищ, які відображають роль метакогнітивної активності в процесі навчання. В першу чергу, досліджуючи точність метакогнітивного моніторингу в контексті навчальної діяльності, постає питання про те, наскільки добре студент усвідомлює власні можливості та обмеження власного пізнання в процесі вирішення навчальних задач. Також, актуальними є питання про вміння студентів ефективно регулювати свою навчальну пізнавальну активність.

Метакогнітивний моніторинг можна розглядати як процес, котрий відноситься до знань когнітивних процесів або результатів цих когнітивних процесів. Як зазначають С. Вард та Г. Кларк, метакогнітивний моніторинг повинен забезпечити плавне та адекватне згідно 3 обраною стратегією мислення (серед яких виділяють використання пауз, перечитування, самотестування), спрямоване на виправлення когнітивного викривлення [12]. Метакогнітивний моніторинг забезпечує індивіда знаннями щодо прийняття рішення про необхідну інформацію та визначає необхідність 
повторного вивчення. Фактично, метакогнітивний моніторинг надає необхідну інформацію, яка підвищує рівень іiі розуміння. Усвідомлення помилки метакогнітивного моніторингу забезпечує основу для виправлення помилок та покращення процесів метапізнання.

Розглядаючи властивості метакогнітивного моніторингу, слід звернути увагу на його точність. Точність метакогнітивного моніторингу дозволяє індивіду успішно користуватись ефективними метакогнітивними стратегіями для досягнення цілей пізнання. Це дає перевагу у плануванні процесів обробки інформації і визначенні ефективних стратегій в майбутньому.

Розглядаючи змістовний аспект метакогнітивного моніторингу, варто взяти до уваги психологічну характеристику рівнів розуміння наукового тексту, запропоновану О. Лазарєвою [15]. На думку дослідниці, процес розуміння наукового тексту, має чотири рівні розвитку. Відповідно, нею проводиться психологічна характеристика мета когнітивних процесів на кожному 3 них. Низький рівень розвитку розуміння наукового тексту характеризується відсутністю стратегій моніторингу, управління інформацією і виправленням помилок. Індивіди 3 таким рівнем розвитку метакогнітивного моніторингу не аналізують власні помилки, не схильні планувати свою діяльність, ставити цілі і прогнозувати результати обробки інформації. На рівні розвитку розуміння наукового тексту нижче середнього характерне несистематичне використання стратегій планування. Індивіди планують процес обробки інформації частково, не звертаючи уваги на поточні результати. Середній рівень розвитку розуміння наукового тексту характеризується розвиненою схильністю до аналізу власної пізнавальної активності i управління нею. Індивіди 3 таким рівнем розвитку метакогнітивного моніторингу мають більш диференційовані, повні знання про стан пізнавальних процесів, їх переваги та недоліки тощо. Використання стратегій метакогнітивного моніторингу на такому рівні дозволяє реалізувати поточний контроль і оцінку процесів розуміння. На високому рівні розвитку розуміння наукового тексту добре розвинена здатність до фіксації уваги на 
ступені зрозумілості інформації, ефективності прийомів розуміння, що застосовуються. Використання стратегій планування надає процесу роботи 3 інформацією цілеспрямований характер, створює базу для управління пізнавальними процесами, стратегіями і процесом розуміння.

Роботи Т. Нельсона та Л. Нарренса виділяють три основні положення щодо перебігу метакогнітивних процесів [9]:

а) ментальні процеси є поєднанням так званого об’єктного рівня (object level), на якому протікають когнітивні процеси, та мета-рівня (meta-level), на якому протікають мета когнітивні процеси;

б) мета-рівень містить у собі динамічну модель об’єктного рівня, яка є джерелом метакогнітивних знань та розуміння самого об’єктного рівня;

в) ці два процеси відповідають перебігу інформації з об'єктного рівня до мета-рівня (що $є$ метакогнітивним моніторингом) та 3 мета-рівня до об’єктного рівня (метакогнітивний контроль).

Екстраполюючи ці дані на особливості перебігу метакогнітивного моніторингу, та його точність, ми можемо зробити наступні висновки. Поперше, метакогнітивний моніторинг виникає під час взаємодії когнітивних та метакогнітивних процесів. По-друге, можна припустити, що точність метакогнітивного моніторингу залежить як від процесу обміну інформацією між цими двома рівнями, так і від особливостей інформації, яка обробляється.

Д. Хакер, Л. Бол описують явища надмірної впевненості та надмірної невпевненості в контексті їх впливу на процес читання. Неточний метакогнітивний моніторинг в процесі читання може підштовхувати студентів до неефективної регуляції запам'ятовування тексту [7]. 3 одного боку, стійка надмірна впевненість впродовж читання може перешкодити процесу моніторингу або контролю досягнення більшого розуміння тексту. 3 іншого боку, стійка надмірна невпевненість може стимулювати студентів до неправильного визначення необхідного часу для обробки інформації. В 
такому випадку студенти думають, що ще недостатньо оволоділи інформацію, хоча насправді це не так.

Судження метакогнітивного моніторингу $є$ важливим джерелом регуляції студентом процесу пізнавальної діяльності під час засвоєння інформації. Очевидно, що у випадку надмірної впевненості, при запам'ятовуванні навчального матеріалу, студент приділятиме мало уваги для його вивчення, оскільки помилково вважатиме, що засвоїв його. Натомість, при недооцінці власних здібностей, студент витрачатиме надмірно багато зусиль та часу для опрацювання інформації.

У роботі Т. Нельсон та Л. Нарренс підкреслюють роль метакогнітивного моніторингу, наголошуючи на важливості взаємодії між метакогнітивним моніторингом та контролем. Автори зазначають, що для розвитку навичок саморегулювання процесу засвоєння інформації студентам необхідно точно моніторити актуальні когнітивні процеси. Отримана інформація використовується в процесі метакогнітивного контролю, функція якого полягає у регуляції когнітивних процесів [9].

Процес навчання, як пише Т. Терешонок, є когнітивним по своїй суті, вимагає осмислення тих дій, які здійснюються в процесі активної інтелектуальної діяльності [3]. I саме метакогнітивні процеси виконують функцію організації індивідом власної інтелектуальної діяльності.

Д. Хакер та Л. Бол аналізують поняття калібрації, яким характеризується точність метакогнітивного моніторингу. Калібрація - це ступінь співвідношення сприйняття власних здібностей індивіда 3 його актуальним здібностями [7].

Наголошуючи на важливості точного метакогнітивного моніторингу, калібрації в процесі навчання, П. Вайн зазначає, що запам’ятовування є обернено пропорційним до кількості помилок, і прямопропорційне точності калібрації [13].

Відсутність вміння точно та реалістично прогнозувати негативно впливає на різні сфери діяльності. Д. Хакер та Л. Бол наводять приклади 
негативного впливу надмірної впевненості не лише в процесі навчання, а й в інших аспектах - наприклад, надмірна впевненість лікаря при постановці діагнозу може загрожувати життю пацієнта, надмірна впевненість юриста щодо вердикту судді або пілота у своїх можливостях управляти літаком в поганих погодніх умовах є небезпечною для життя пасажирів [7]. В навчальній аудиторії надмірна впевненість також має негативні наслідки, хоча i не несе загрози життю. Вона впливає на ефективність навчальної діяльності та мотивацію студентів до навчання. Так, студенти, котрі $є$ надмірно невпевненими, можуть помилково розтягувати час, необхідний для підготовки до тестів, оскільки постійно вважають, що не досягли необхідного рівня знань. Стійка надмірна впевненість під час використання стратегій запам'ятовування може забезпечувати помилкове відчуття того, що обрана стратегія є ефективною.

Постає питання, як саме впливає точність метакогнітивного моніторингу на успішність здійснення навчальної діяльності. Цей вплив можна узагальнити в наступних твердженнях:

1. Високі показники розвитку моніторингу, виміряні за допомогою різних варіантів опитувальників, позитивно корелюють 3 навчальними досягненнями і успішністю виконання тестів знань;

2. Учні та студенти, які демонструють більш точний метакогнітивний моніторинг успішності виконання тестів знань, мають більш високі бали по цим тестам, а також мають більш високі показники навчальної успішності;

3. Учні та студенти, які демонструють низькі показники виконання тестів знання, а також невисоку академічну успішність, схильні переоцінювати свої знання [2].

Більшість досліджень підтверджують припущення про те, що студенти 3 низьким рівнем академічної успішності схильні перебільшувати власну компетентність. А. Коріат вказує, що така особливість студентів є проявом 
стратегії самопідтримки. Тобто, коли можливості та здібності є обмеженими, прояв надмірної впевненості може бути стратегією захисту [8].

Точність метакогнітивного моніторингу та здібності впливають один на одного. Так, вміння студента визначити наскільки добре він підготувався до екзамену, моніторити власні знання протягом нього є суттєвою навичкою, котра сприяє розвитку тих самих здібностей. Тоді як здібності та знання також впливають на точність метакогнітивного моніторингу.

У дослідженнях Е. Савіна та А. Фоміна було встановлено, що студенти 3 низьким та середнім рівнями засвоєння знання опираються при винесенні суджень впевненості, по-перше, на загальну суб'єктивну оцінку власної успішності, по-друге, на досвід навчання в схожій області. Як пояснюють автори, при недостатньому володінні предметним знанням надмірний оптимізм (надмірна впевненість) в судженнях демонструють перш за все ті студенти, які в цілому вважають себе успішними в процесі навчання i отримували раніше позитивні оцінки з предмету. Лише при достатньо високому рівні засвоєння предметно-специфічного знання моніторинг опирається на безпосередню актуалізацію. Отже, на думку авторів, співвідношення між предметним знанням і метакогнітивним моніторингом не відповідає інтуїтивному переконанню про те, що високий рівень засвоєння інформації сприятиме більшій впевненості [2].

3 цим твердженням згодні й інші автори: П. Вайн та Д. ДжеймсонНоель дослідили, що студенти можуть помилятись під час самоконтролю ефективності технік навчання [14]. Вчені з'ясували, що у студентів частіше з'являється надмірна впевненість в тому випадку, коли вони використовують послідовні методи вивчення інформації, та планують цей процес. Таким чином, відповіді з надмірно впевненими передбаченнями можуть бути спричинені неналежною самооцінкою ефективності будь-якої конкретної стратегії дослідження, що використовується. Загальна тенденція проявів явища надмірної впевненості або невпевненості заключається у так званому ефекті «складності-легкості»: у разі підвищеної складності матеріалу 
студенти більше впевнені у правильності своїх знань, а в випадку легкості матеріалу студенти схильні до надмірної невпевненості. Тому, студенти можуть виділяти меншу кількість часу для засвоєння складного матеріалу, на який потрібно значно більше часу. У ситуації проходження тесту студенти можуть не переглядати повторно свої відповіді, оскільки невиправдано впевнені у їх правильності.

Точність калібрації пов’язана 3 рівнем досягнень студентів. Дослідниками присвячено значну кількість робіт щодо особливостей моніторингу в умовах перевірки засвоєної інформації (екзамени).

Так, студенти, які мають низький рівень навчальних досягнень, схильні демонструвати низьку точність та надмірну впевненість під час екзаменів. Тоді як студенти з високим рівнем навчальних досягнень схильні до вищої точності метакогнітивного моніторингу, однак демонструють надмірну невпевненість. Така тенденція була помічена серед студентів різних спеціальностей різних років навчання, тобто не залежить від досвіду або інших чинників.

Як зазначає А. Коріат, були виявлені значні кореляції між рівнем досягнень та особливостями метакогнітивного моніторингу на екзамені [8]. Ним було помічено наступне: у студентів 3 високим рівнем академічної успішності точність калібрації не залежала від типу завдання (завдання 3 вибором варіантів відповіді та завдання 3 відкритою відповіддю). Тоді як студенти з низьким рівнем академічної успішності були менш точними у оцінці правильності виконання завдань 3 вибором варіантів. Л. Болл та інші 3’ясували, що така тенденція існує як i в судженнях, що передують виконанню завдання, так і в судженнях після виконання цього завдання [7].

А. Коріат зазначає, що менш здібні студенти під час оцінки засвоєння інформації демонстрували нездатність відрізнити відому та невідому інформацію []8. Ф. Сінкевич виявив більшу кореляцію між оцінкою впевненості у свої можливостях та реальними здібностями серед більш успішних студентів, порівнюючи їх з менш успішними студентами [11]. Л. 
Гарвалія і М. Кредлер виявили обернений зв'язок між очікуваними оцінками 3 їхніми реальними балами [6].

Дослідники зазначають, що наявність зв'язку між точністю калібрації та рівнем навчальних досягнень $є$ очевидною, однак характер цього зв’язку залежить від тестового завдання. Дж. Нетфілд вимірював калібрацію студентів різних курсів на загальному рівні (визначаючи оцінки загального засвоєння інформації) та локальному рівні (оцінка студентом правильності відповіді на кожне запитання) [10]. Так, студенти з вищим рівнем розвитку здібностей продемонстрували більш точну калібрацію, ніж студенти 3 нижчим рівнем розвитку здібностей.

Також, встановлено, що студенти проявляли більш точний моніторинг в простіших питаннях, тоді як у складніших частіше проявлялась надмірна впевненість або невпевненість. Л. Флейнелі, П. Джаслін та А. Вінман встановили, що студенти демонструють надмірну невпевненість у простих питаннях, а надмірну впевненість - у складних [5].

Особливої уваги заслуговує той факт, що такі тенденції помітні лише під час оцінки кожного питання окремо. Вимірюючи точність суджень про засвоєння інформації в цілому, ряд авторів (Л. Бол, Д. Хакер) не виявили жодного зв'язку з калібрацією та рівнем досягнень [7].

Варто відзначити, що дослідження вищезгаданих авторів суперечить дослідженням А. Коріат, в якому виявлено значний зв'язок між рівнем навчальних досягнень та надмірною впевненістю (надмірною невпевненістю) [8]. Зокрема, точність калібрації студентів 3 високим рівнем навчальних досягнень не відрізняється в залежності від типу питання - відповіді 3 вибором варіантів або відкриті відповіді. Натомість, студенти з нижчим рівнем навчальних досягнень були менш точними у їх передбаченнях правильності відповіді на питання 3 варіантами вибору. Цей факт пояснюється тим, що питання, які передбачали варіанти відповіді, були складнішими, ніж питання з відкритою відповіддю. Тому, студенти з нижчим рівнем навчальної успішності, які гірше засвоїли інформацію, що 
перевірялась, демонстрували нижчу точність в оцінці складних питань. Л. Флейнелі встановила, що в випадку оцінки правильності кожної відповіді окремо, відсутні будь-які відмінності в точності метакогнітивного моніторингу в розрізі навчальної успішності [5].

Також, Дж. Барнет та Дж. Хайксон, досліджуючи судження різного типу про здібності, отримали наступні результати: в цілому, загальні судження про правильність відповіді мали значну кореляцію з навчальними досягненнями [4]. Високі показники точності суджень про правильність відповіді корелювали з успішними результатами тестів. Вони виявили вікові особливості точності метакогнітивного моніторингу: так, старші студенти були менш точними у своїх судженнях, а молодші - більш точними.

Точність метакогнітивного моніторингу в процесі навчальної діяльності досліджується не лише як характеристика студентів, але як і характеристика педагога. Е. Савін наголошує, що важливим $є$ вміння педагога транслювати адекватні метакогнітивні знання та стратегії студентам [2]. Автор наголошує і про важливість та необхідність розробки спеціальних навчальних процедур, спрямованих на підвищення якості мета когнітивної активності учасників навчального процесу. Так, Т. Доцевич, пишучи про абнотивність - важливу складову педагогічної компетентності, що сприяє професійному та особистому зростанню викладачів, а також розвитку креативності студентів, наголошує на тому, що один з іiі компонентів - це розвиток процесів метакогнітивного моніторингу та рефлективність [1]. Т. Терешонок та С. Бакшеєва наголошують, що навчальна діяльність $€$ двостороннім процесом: учіння - свідома активна діяльність по оволодінню знаннями, уміннями та навиками; викладання - діяльність педагога про представленню навчального матеріалу [3].

В цілому, А. Фомін пише про те, що існують істотні протиріччя щодо місця метакогнітивного моніторингу в організації пізнавальної діяльності. 3 одного боку, якість метакогнітивного моніторингу $\epsilon$ умовою успішного виконання начальних задач [2]. Загальна тенденція полягає в тому, що 
студенти, які більш точно оцінюють власні знання, усвідомлюють власні стратегї роботи з матеріалом, мають вищу академічну успішність. 3 іншого боку, існує велика кількість досліджень, які свідчать про обмеженість метакогнітивного моніторингу. I в основному ця обмеженість проявляється в переоцінці власних пізнавальних можливостей, а також у надмірній впевненості індивіда стосовно правильності виконання завдань.

Висновки 3 проведеного дослідження. Точність метакогнітивного моніторингу - важливий чинник успішності навчальної діяльності. Оскільки проаналізовані нами дані базуються в основному на зарубіжних експериментах, то перспектива подальших досліджень полягає у емпіричному вивченні точності метакогнітивного моніторингу в умовах українських вищих навчальних закладів.

\section{Список використаних джерел}

1. Доцевич T. I. Шляхи та засоби діагностики метакогнітивної компетентності викладачів / T. I. Доцевич // Вісник Харківського національного педагогічного університету ім. Г. С. Сковороди. Психологія: наукове видання. - Харків, 2013. - Вип. 46, Ч. 2. - С. 62-75.

2. Лазарева О. В. Формирование метакогнитивной регуляции понимания научного текста [Електронний ресурс] / Ольга Викторовна Лазарева // Электронное научное издание (научно-педагогический интернетжурнал) "The Emissia.Offline Letters". - 2012. - Режим доступу до ресурсу: http://www.emissia.org/offline/2012/1843.htm

3. Савин Е. Ю. Метакогнитивный мониторинг в решении учебных задач: соотношение обобщенных и предметно-специфических навыков / Е. Ю. Савин, А. Е. Фомин // Шестая международная конференция по когнитивной науке: Тезисы докладов. - Калининград, 2014. - С. 533-53.

4. Терешонок Т. В. Метакогнитивные компоненты в структуре учебной деятельности / Т. В. Терешонок, С. С. Бакшеева. // Социальноэкономический и гуманитарный журнал Красноярского ГАУ. - 2015. - №1. C. $175-180$. 
5. Barnett J. E. Effects of grade level and subject on test score predictions /J. E. Barnett, Hixon J. E. // The Journal of Education Research, 1997, — No 90, - P. 170-174.

6. Flannelly L.T. Reducing people's judgment bias about their level of knowledge / L.T. Flannelly, K.J. Flannelly / The Psychological Record, 2000. Vol. 50. - pp. 587-600.

7. Garavalia L. S. An exploratory study of academic goal settings, achievmrnt calibration and self-regulated learning / L. S. Garavalia, M. E. Gredier // Journal of Instructional Psyhology, 2002. — Vol.29, — P. 221-230.

8. Hacker D. J. Metacognition in education: A focus on calibration / D. J. Hacker, L. Bol, M. C. Keener // In J. Dunlosky and R. Bjork (Eds.), Handbook of Memory and Metacognition. - Mahwah, NJ: Lawrence Erlbaum Associates, 2008. - pp. $429-455$

9. Koriat A. Dissociating knowing and the feeling of knowing: Further evidence for the accessibility model / A. Koriat // Journal of Experimental Psychology: General, 1995. - Vol. 124, No. 3. - pp. 311-333.

10. Nelson T. Metamemory; a theoretical framework and new findings / T. Nelson, L. Narrens // Pshychology of Learning and Motivation / In G. Browner (Ed.). - New York^Academic press, 1990. P. 125-147.

11. Nietfeld J. L. Metacognitive monitoring accuracy and student performance in the postsecondary classroom / J. L. Nietfeld, L. Cao, J. W. Osborne // The Journal of Experimental Education, 2005. - Vol. 74, No. 1. - pp. 7-28.

12. Sinkavich F. J. Performance and metamemory: Do students know what they don't know? / F. J. Sinkavich // Journal of Instructional Psyhology, 1995. - Vol. 22, - P. 77-87.

13. Ward S. B. The effect of feedback on the illusion of knowing and comprehension monitoring of college students / S. B. Ward, H. T. Clark, III // Paper presented at the Annual Meeting of the Eastern Educational Research Association, 1989. - $18 \mathrm{p}$ 
14. Winne P. H. Studying as self-regulated learning / P. H. Winne, A. F., Hadwin // In D. J. Hacker, J. Dunlosky, A. C. Graesser (Eds.), Metacognition in Educational Theory and Practice, 1998. - pp. 277-304.

15. Winne P. H. Exploring student's calibration of self-reports about study tactics and achievement. / P. H. Winne, D. L. Jamieson-Noel // Contemporary Educational Psyhology, 2002. - Vol. 22, - P. 551-572.

\section{References transliterated}

1. Docevych T. I. Shlyaxy ta zasoby diahnostyky metakohnityvnoyi kompetentnosti vykladachiv / T. I. Docevych // Visnyk Xarkivs"koho nacional"noho pedahohichnoho universytetu im. H. S. Skovorody. Psyxolohiya: naukove vydannya. - Xarkiv, 2013. - Vyp. 46, Ch. 2. - S. 62-75.

2. Lazareva O. V. Formyrovanye metakohnytyvnoj rehulyacyy ponymanyya nauchnoho teksta [Elektronnyj resurs] / Ol"ha Vyktorovna Lazareva // Эlektronnoe nauchnoe yzdanye (nauchno-pedahohycheskyj ynternet-zhurnal) "The Emissia.Offline Letters". - 2012. - Rezhym dostupu do resursu: http://www.emissia.org/offline/2012/1843.htm

3. Savin E. Ju. Metakognitivnyj monitoring v reshenii uchebnyh zadach: sootnoshenie obobshhennyh i predmetno-specificheskih navykov / E. Ju. Savin, A. E. Fomin // Shestaja mezhdunarodnaja konferencija po kognitivnoj nauke: Tezisy dokladov. - Kaliningrad, 2014. - S. 533-53.

4. Tereshonok T. V. Metakognitivnye komponenty v strukture uchebnoj dejatel'nosti / T. V. Tereshonok, S. S. Baksheeva. // Social'no-jekonomicheskij i gumanitarnyj zhurnal Krasnojarskogo GAU. - 2015. - \#1. - S. 175-180.

5. Barnett J. E. Effects of grade level and subject on test score predictions /J. E. Barnett, Hixon J. E. // The Journal of Education Research, 1997, — No 90, - P. 170-174.

6. Flannelly L.T. Reducing people's judgment bias about their level of knowledge / L.T. Flannelly, K.J. Flannelly / The Psychological Record, 2000. Vol. 50. - pp. 587-600. 
7. Garavalia L. S. An exploratory study of academic goal settings, achievmrnt calibration and self-regulated learning / L. S. Garavalia, M. E. Gredier // Journal of Instructional Psyhology, 2002. — Vol.29, — P. 221-230.

8. Hacker D. J. Metacognition in education: A focus on calibration / D. J. Hacker, L. Bol, M. C. Keener // In J. Dunlosky and R. Bjork (Eds.), Handbook of Memory and Metacognition. - Mahwah, NJ: Lawrence Erlbaum Associates, 2008. - pp. 429-455

9. Koriat A. Dissociating knowing and the feeling of knowing: Further evidence for the accessibility model / A. Koriat // Journal of Experimental Psychology: General, 1995. - Vol. 124, No. 3. - pp. 311-333.

10. Nelson T. Metamemory; a theoretical framework and new findings / T. Nelson, L. Narrens // Pshychology of Learning and Motivation / In G. Browner (Ed.). - New York^Academic press, 1990. P. 125-147.

11. Nietfeld J. L. Metacognitive monitoring accuracy and student performance in the postsecondary classroom / J. L. Nietfeld, L. Cao, J. W. Osborne // The Journal of Experimental Education, 2005. - Vol. 74, No. 1. - pp. 7-28.

12. Sinkavich F. J. Performance and metamemory: Do students know what they don't know? / F. J. Sinkavich // Journal of Instructional Psyhology, 1995. — Vol. 22, — P. 77-87.

13. Ward S. B. The effect of feedback on the illusion of knowing and comprehension monitoring of college students / S. B. Ward, H. T. Clark, III // Paper presented at the Annual Meeting of the Eastern Educational Research Association, 1989. - $18 \mathrm{p}$

14. Winne P. H. Studying as self-regulated learning / P. H. Winne, A. F., Hadwin // In D. J. Hacker, J. Dunlosky, A. C. Graesser (Eds.), Metacognition in Educational Theory and Practice, 1998. - pp. 277-304.

15. Winne P. H. Exploring student's calibration of self-reports about study tactics and achievement. / P. H. Winne, D. L. Jamieson-Noel // Contemporary Educational Psyhology, 2002. - Vol. 22, - P. 551-572. 